dents. These institutions might offer some master's programs as well, but there will be little research and activities will concentrate mainly on teaching. The interesting areas in this kind of institutional diversification will be at the margins, involving movement from the top group to the middle group and vice versa as well as movement from the middle group to the lower group and vice versa. This does not necessarily entail a determination of a certain place for each individual institution on a given ranking list but rather a grouping or clustering.

What can be observed already now is the fact that this initiative did indeed trigger a lot more competition among German universities than ever before. Whether it will also turn out to be the first step in establishing a ranking of German universities remains to be seen.

\section{Shaping a New Higher Education Policy for Jamaica}

\section{TERENCE Frater}

Terence Frater is a doctoral candidate and graduate assistant in the Comparative, International, Development Education Centre at the Ontario Institute for Studies in Education, University of Toronto. E-mail: tfrater@oise.utoronto.ca.

When Jamaica included its higher education sector in the General Agreement on Trade in Services (GATS), it exposed the sector to the regulatory framework of the World Trade Organization (WTO). The country became committed to GATS out of a political culture of liberalization and a desire to expand access in the sector. Greater participation by foreign providers was expected to facilitate this expansion, although there were no clear policy strategies or appropriate regulatory mechanisms to cope with the emerging dynamics within the sector. This commitment has recently been reaffirmed, however, at a time when the higher education system is required to support national development and serve as a foundation for social mobility. Jamaica must now endeavor to craft a policy framework for the sector that captures its strategic intent while complying with its obligations as a member of the WTO.

\section{Higher Education Institutional Arrangements}

Higher education of any sort did not materialize for Jamaica until the I83os, when colleges began to be established for the first time in the small British colonies of the Caribbean. The first university, the University of the West Indies, was established in 1948 in Jamaica, to serve all these English-speaking countries. The country has done much since attaining independence in I962, and more so since the reforms of the I970s, to make higher education accessible to the average Jamaican.
The higher education landscape now consists of four universities (two private and two public), and includes six teachers colleges, five community colleges, and several technical/vocational training institutes, specialist colleges, and professional educational associations. This is the most diverse institutional framework in the English-speaking Caribbean.

\section{Foreign Higher Education Providers}

In the face of limited public resources to expand access, the participation of foreign providers is fully supported by Jamaican policymakers. These providers supply higher educational services using all the modalities specified in the GATS classifications. Within the last decade, their number has climbed from 3 to Io, and others are in discussions to enter the marketplace. Owing to their flexibility, foreign providers attract students who fail to meet the matriculation requirements of the public institutions or who are excluded as a result of infrastructure limitations. More significantly, however, they meet the needs of previously underserved working professionals who can now pursue programs at times and places that more conveniently fit their home and work schedules.

Concerns have recently been raised about the role of these foreign providers and the quality of their programs. With the creation of the University Council of Jamaica in 1987, the country has managed to maintain a high standard of outcomes through a rigorous accreditation process. Thus far, foreign institutions have sought accreditation for all their programs.

Jamaica must now endeavor to craft a policy framework for the sector that captures its strategic intent while complying with its obligations as a member of the WTO.

However, the institutional diversity that now exists and the increased complexity of supplying higher education services present challenges for the council based on its original mandate and regulatory authority. Steps are therefore being taken to strengthen the legislative framework that governs the council and to modernize its capabilities, which will ensure that it can continue to function effectively in the emerging paradigm. The government has committed to providing the necessary resources to accomplish this task.

\section{Jamaica's Higher Education Policy Imperatives}

Jamaica emerged from its ideological struggles of the I970s and I980 embracing the free-market economic model and determined to "free up" the economy with the acceleration of privatization and liberalization. The higher education sector today is a reflection of the country's colonial past and this independent-minded approach to the future. However, in the face 
of a conceptualization of liberalization that is framed and regulated by the WTO, and which impacts the way countries craft national policies and regulatory frameworks, Jamaica is striving to understand what this means for its 2.7 million population.

With increasing evidence that national considerations of more powerful developed countries shape and often take precedence over international arrangements in conflict with their national interests and global obligations, smaller developing countries like Jamaica appear disadvantaged, because they lack the knowledge capacity to participate equitably on the international stage. To cope with this dynamic, Jamaica must accelerate the process of providing greater access to higher education. Within this context, the sector is evolving as the underpinning of the socioeconomic development of the nation but needs to integrate more closely with other crucial sectors of society.

\section{Policy Strategy}

Jamaican policymakers acknowledge the need to expand participation in higher education if the country is to narrow the knowledge gap with its major trading partners in terms of economic development. Particular challenges arise because of the

\section{Jamaica must accelerate the process of providing greater access to higher education.}

high levels of violent crime that exist (averaging I,IO० murders per year over the last Io years), and the high rate of migration among its graduates (with some estimates as high as 80 percent). Thus, making progress will not be easy, but Jamaica has to find the wherewithal to craft a coherent and visionary higher education policy that takes these contextual factors into account. To develop the human capital necessary to sustain growth and strengthen the country's global competitiveness requires policies that result from a strategy that articulates the vision, purpose, and objectives of the sector. In a real sense, therefore, higher education has the potential to underpin the country's revival, based on a profound understanding of the dynamics that prevail.

Jamaica is not the only country that needs to maneuver itself out of a difficult socioeconomic situation where higher education becomes the lever to facilitate recovery and even prosperity. However, the country also finds itself having to cope with WTO regulations, which impose obligations regarding liberalization, market access, and transparency.

At this juncture, Jamaica clearly needs consensus around its higher education policy, as only then can the policy environment honor the participation of all stakeholders, meet national objectives, and comply with WTO obligations. This policy framework must specifically address the concerns related to the GATS, clarify the role of foreign providers, ensure greater articulation in the system, strengthen the certification and accreditation mechanisms, and be more tightly linked with other key policy areas.

\section{Expansion and Quality in Bangladesh}

\section{Yuto Kitamura}

Yuto Kitamura is associate professor of international development at Nagoya University, Japan, and a visiting professor at the Japan Study Center at the University of Dhaka, Bangladesh (2005-2006). Address: Nagoya University, Furo-cho, Chikusa-ku, Nagoya 464-8601, Japan. Email: yuto@gsid.nagoya-u.ac.jp.

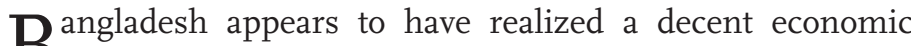
B development since the late I990s. The United Nations Development Program's Human Development Report recently ranked this nation in the middle levels of development. Reflecting the advances in economic and social development, higher education in Bangladesh has shown a significant expansion in recent years, particularly in the private sector.

\section{UniVersities IN THE SyStem}

Bangladesh has two main, separate types of higher education institutions: the highly competitive universities and a large number of degree colleges affiliated with universities. This article examines only those educational institutions categorized as universities by the University Grants Commission (UGC) - this discussion does not address the affiliated colleges or other important streams in the tertiary level of the Bangladesh education system (i.e., madrasah education).

In Bangladesh, at present, there are 75 universities $(2 \mathrm{I}$ in the public sector and 54 in the private sector), which grant diplomas in specific fields as well as bachelor's and higher degrees. For most individuals in this developing nation, access to a university education has been limited. The Bangladesh: Education Sector Review (2000), published by the World Bank, pointed out that less than io percent of the students who obtained the Higher Secondary Certificate were admitted to universities. The poor inevitably have been excluded from the education system prior to reaching the tertiary level.

\section{Rapid Expansion of the Private Sector}

The expansion of Bangladeshi higher education in recent years has largely been due to the rapid growth of the private sector. With the Private University Act in 1992, the government approved the establishment of North South University, the first private university in Bangladesh. During the I990s, around 20 government-recognized private universities were established, 